\title{
KOMPETISI ANTARA TANAMAN SORGUM DENGAN ROTTBOELLIA
}

(Competition of Sorghum and Rottboellia exaltata L.F.)

\author{
Danner Sagala ${ }^{1}$, Leo Mualim ${ }^{2}$, Didi Darmadi ${ }^{3}$ \\ ${ }^{1}$ Fakultas Pertanian Universitas Prof. Dr. Hazairin, $\mathrm{SH}$ \\ ${ }^{2}$ Mahasiswa Program Doktor Institut Pertanian Bogor \\ ${ }^{3}$ Balai Penyuluh Pertanian Nangroe Aceh Darussalam
}

\begin{abstract}
This research was aimed to study the competitiveness of shorgum and Rottboellia exaltata L.f.. The experiment was done at glass house, experimental station of SEAMEO-BIOTROP, Bogor on 3 Oktober - 17 November 2009. The main plant was Sorghum and the weed was Rottboellia exaltata L.f.. the result showed that the sorghum was more competitive than Rottboellia exaltata L.f..
\end{abstract}

Key words: Competition, Sorghum, Rottboellia exaltata L.f., weed

\section{PENDAHULUAN}

Kehadiran gulma dapat memberikan dampak negatif bagi usaha budidaya tanaman, baik terhadap hasil tanaman budidaya maupun terhadap proses produksi. Dampak kerugian yang ditimbulkan antara lain menurunkan hasil pertanian akibat persaingan dalam hal sumberdaya yang tersedia, menurunkan mutu hasil pertanian akibat campuran biji gulma maupun bagian lainnya, merupakan tanaman inang hama dan penyakit, mengakibatkan keracunan bagi tanaman pokok akibat senyawa allelopati, mempersulit atau menghambat pekerjaan di lapangan dan pengelolaan hasil, menghambat atau merusak peralatan, menurunkan debit air, menurunkan kualitas air, menghambat lalu lintas air, irigasi dan turbin listrik, pendangkalan perairan, dan akibatnya akan menambah biaya produksi (Madkar et al., 1986). Sukman dan Yakup (1991) menyatakan bahwa pada sistem pertanian di wilayah Jawa diperlukan input sebesar $17 \%$ dan di Sumatera sebesar 27\% akibat gulma.

Dampak negatif kehadiran gulma pada lahan pertanaman budidaya sangat bervariasi karena dipengaruhi oleh iklim, jenis tanaman, jenis gulma, mekanisme asosiasi gulma dan tanaman serta praktek pertanian. Diantara mekanisme assosiasi gulma dan tanaman, kompetisi atau persaingan merupakan salah satu mekanisme asosiasi yang dapat menurunkan hasil produksi tanaman. Sastroutomo (1990) menyatakan bahwa persaingan antara gulma dan tanaman pokok adalah persaingan inter spesifik (inter spesific competition) yang karena terjadi antar spesies tumbuhan yang berbeda, sedangkan persaingan yang terjadi antara spesies tumbuhan yang sama merupakan persaingan intraspesifik (intraspesific competition). Kompetisi dapat terjadi jika salah satu dari dua atau lebih oganisme yang hidup bersama-sama membutuhkan faktor lingkungan yang sangat terbatas persediaannya dan tidak mencukupi bagi kebutuhan bersama. Kompetisi dapat diartikan juga sebagai periode dimana gulma tumbuh bersama-sama dengan tanaman budidaya meskipun belum diketahui secara pasti apakah terjadi persaingan diantara keduanya terhadap faktor-faktor pertumbuhan dalam jumlah minimal.

IRRI (1976) mengemukakan bahwa gulma yang menimbulkan kerugian paling besar biasanya gulma rumput berdaun sempit yang dapat mengurangi hasil sorgum sebanyak 90\% dibandingkan gulma berdaun lebar. Rottboellia exaltata L.f. adalah satu diantara gulma daun sempit penting dalam budidaya tanaman, termasuk sorgum.

Selain memiliki potensi sebagai sumber karbohidrat, tanaman sorgum, mempunyai keistimewaan lebih tahan terhadap kekeringan dan genangan bila 
dibandingkan dengan tanaman palawija lainnya serta dapat tumbuh hampir disetiap jenis tanah. Mengingat potensi serta keistimewaannya itu, sorgum sebenarnya layak dikembangkan terutama untuk menunjang upaya-upaya pelestarian swasembada beras (Balai Informasi Pertanian Provinsi Irian Jaya, 1990).

Berdasarkan hal tersebut maka dilakukan percobaan tentang kompetisi antara tanaman sorgum (Sorghum bicolor) dengan Rottboellia exaltata L.f. yang bertujuan untuk mengetahui kemampuan kompetisi dari tanaman sorgum dengan gulma Rottboellia exaltata L.f..

\section{BAHAN DAN METODE}

Percobaan ini dilaksanakan pada tanggal 3 Oktober - 17 November 2009 di rumah kaca kebun Percobaan SEAMEOBIOTROP, Bogor. Jenis tanaman utama yang digunakan adalah Sorghum dan jenis gulma yang digunakan adalah Rottboellia exaltata L.f.. Perlakuan adalah kombinasi populasi sorgum dan gulma dengan 4 (empat) ulangan. Kombinasi yang digunakan adalah:

Perlakuan Monokultur :

1. Sorghum populasi 6

2. Sorghum populasi 12

3. Sorghum populasi 18

4. Sorghum populasi 24

5. Sorghum populasi 30

6. Sorghum populasi 36

7. R.exaltata populasi 6

8. R.exaltata populasi 12

9. R.exaltata populasi 18

10. R.exaltata populasi 24

11. R.exaltata populasi 30

12. R.exaltata populasi 36

Perlakuan Campuran :

1. Sorghum : R.exaltata $(36: 0)$

2. Sorghum : R.exaltata $(30: 6)$

3. Sorghum : R.exaltata $(24: 12)$

4. Sorghum : R.exaltata $(18: 18)$

5. Sorghum : R.exaltata $(12: 24)$

6. Sorghum : R.exaltata $(6: 36)$
Benih sorghum dan gulma R.exaltata disemai dalam pot plastik berisi tanah. Pot plastik dengan volume 2 liter diisi dengan tanah dan pupuk kandangn dengan perbandingan 3:1. Tanaman kemudian dipelihara dan selama pemeliharaan diberikan pengairan setiap hari. Setelah enam minggu dilakukan pengamatan kompetisi. Tanaman sorghum dan gulma dicabut kemudian diambil bagian vegetatif di atas tanah. Seluruh tanaman dimasukkan dalam kantong kertas dan dioven untuk memperoleh data berat keringnya. Data yang diperoleh dianalisis untuk melihat tingkat kompetisi dari setiap perlakuan yang dilakukan.

Percobaan kompetisi yang dilakukan adalah tipe replacement series, antara sorghum dan rumput R.exaltata yang ditanam di pot 2 lt dengan populasi 36 tumbuhan per pot, dan replacement series dari $0,1 / 6,1 / 3,1 / 2$, dan 1 bagian, sehingga populasi masing jenis adalah 0,$36 ; 6,30$; 12,$24 ; 18,18 ; 24,12 ; 30,6 ; 36,0$ untuk masing-masing sorghum dan R.exaltata.

Analisis monokultur untuk menghitung nilai $\beta$ dikerjakan berdasarkan hubungan antara kerapatan dan biomassa.

\section{HASIL DAN PEMBAHASAN Kompetisi Intraspesifik (Monokultur)}

Berat kering sorgum pada tanaman monokultur meningkat hingga populasi 18 , kemudian menurun pada populasi 24 namun melandai hingga populasi 36. Pada monokultur $R$. exaltata terjadi peningkatan berat kering dengan semakin meningkatnya populasi per pot (Tabel 1 dan Gambar 1).

Pada monokultur sorghum ditemukan adanya serangan hama Aphids pada pot dengan populasi 24, 30 dan 36. Hal ini diduga menjadi penyebab menurunnya bobot kering sorghum pada populasi ini. Namun demikian persaingan antar individu dalam spesies menyebabkan sumberdaya yang terbatas semakin berkurang dan akhirnya laju pertambahan biomassa semakin melambat dan berkurang serta terjadi pelandaian (leveling off). 
Tabel 1. Bobot kering sorghum dan R.exaltata yang ditanam secara monokultur dan polikultur.

\begin{tabular}{|c|c|c|c|c|}
\hline \multirow{2}{*}{ No } & \multirow{2}{*}{ Perlakuan } & \multicolumn{2}{|c|}{ Bobot kering (g) } & \multirow{2}{*}{ Ket } \\
\hline & & Sorgum & Rottboellia & \\
\hline 1 & Sorghum 6 & 11.45 & & \\
\hline 2 & Sorghum 12 & 14.06 & & \\
\hline 3 & Sorghum 18 & 16.52 & & \\
\hline 4 & Sorghum 24 & 12.86 & & Aphid \\
\hline 5 & Sorghum 30 & 12.28 & & Aphid \\
\hline 6 & Sorghum 36 & 12.61 & & Aphid \\
\hline 7 & Rottboellia 6 & & 11.36 & \\
\hline 8 & Rottboellia 12 & & 14.45 & \\
\hline 9 & Rottboellia 18 & & 13.95 & \\
\hline 10 & Rottboellia 24 & & 13.37 & \\
\hline 11 & Rottboellia 30 & & 14.28 & \\
\hline 12 & Rottboellia 36 & & 15.44 & \\
\hline 13 & Sorghum 36 - Rottboellia 0 & 10.11 & 0.00 & \\
\hline 14 & Sorghum 30 - Rottboellia 6 & 6.73 & 5.04 & \\
\hline 15 & Sorghum 24 - Rottboellia 12 & 6.75 & 8.54 & \\
\hline 16 & Sorghum 18 - Rottboellia 18 & 3.95 & 8.70 & \\
\hline 17 & Sorghum 12 - Rottboellia 24 & 3.27 & 8.94 & \\
\hline 18 & Sorghum 6 - Rottboellia 30 & 3.23 & 8.98 & \\
\hline 19 & Sorghum 0 - Rottboellia 36 & 0.00 & 15.22 & \\
\hline
\end{tabular}

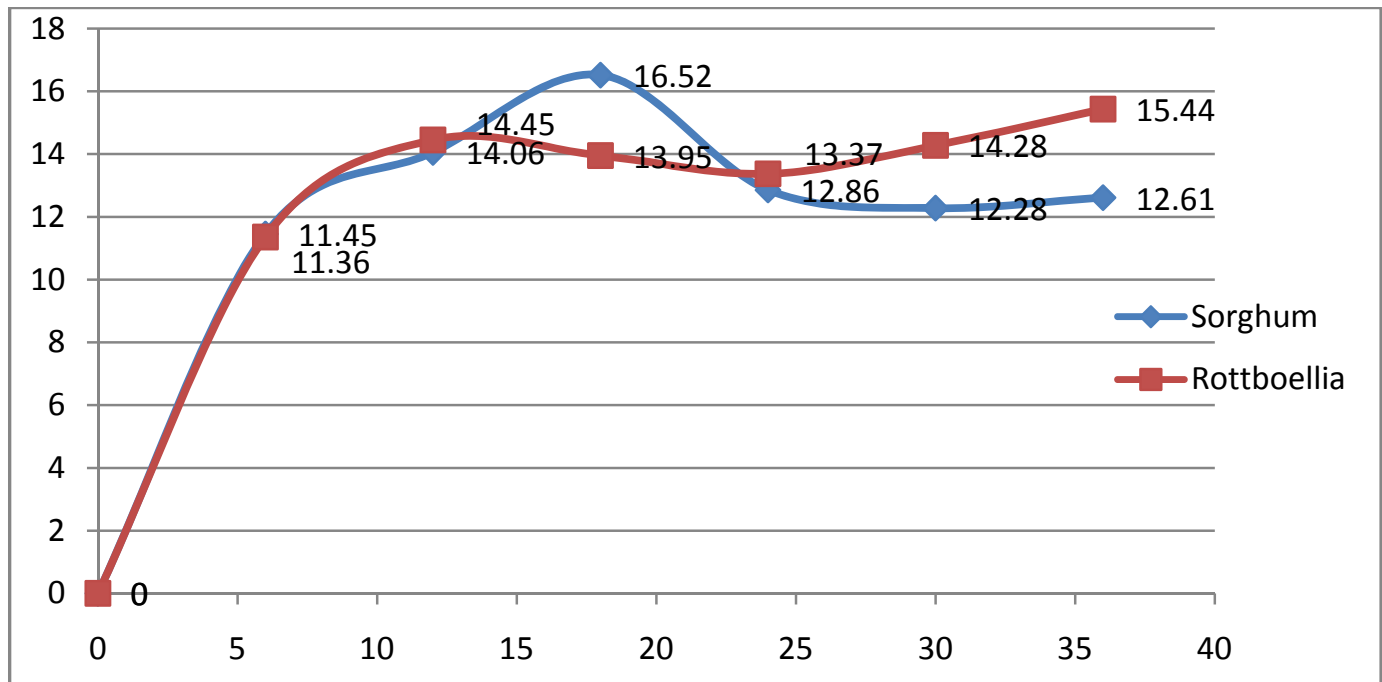

Gambar 1. Kurva Hubungan populasi dan biomassa pada tanaman sorgum dan gulma rottbellia pada sistem monokultur 


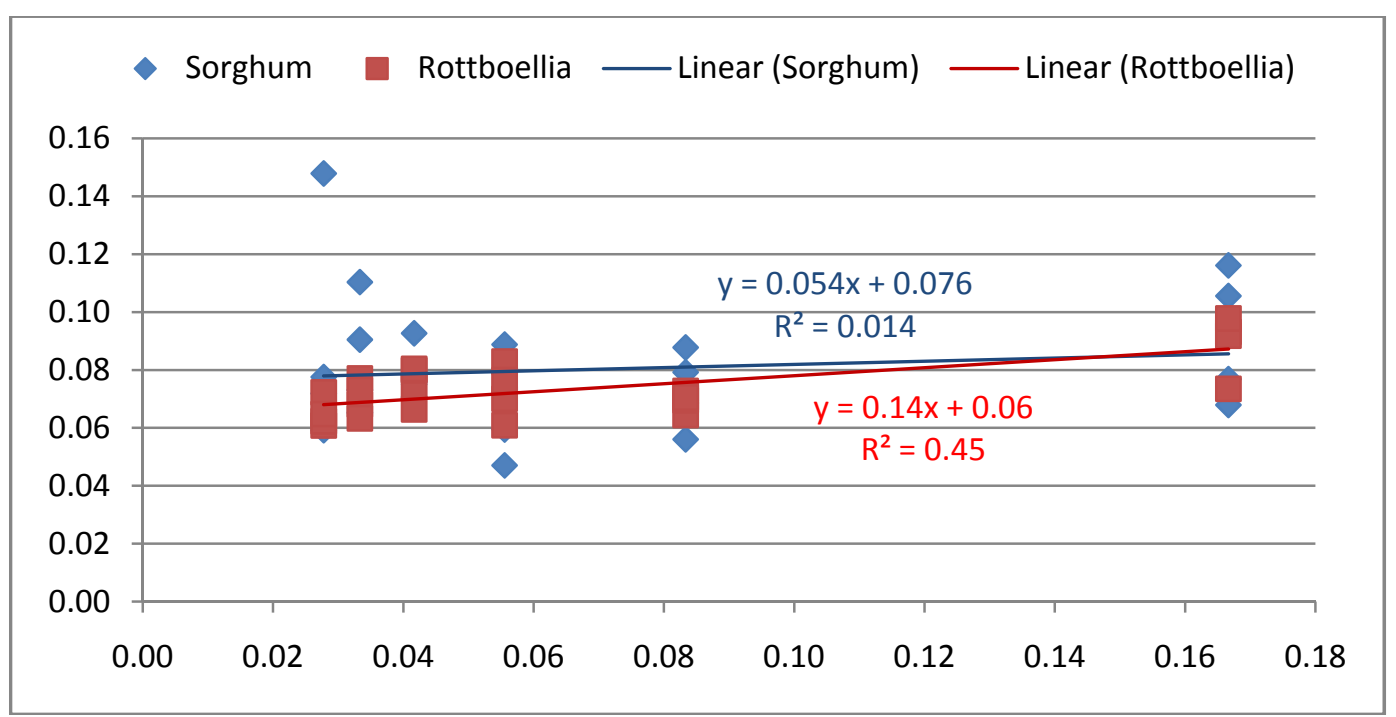

Gambar 2. Kurva regresi linear kemampuan kompetisi intraspesifik tanaman sorgum dan gulma R.exaltata

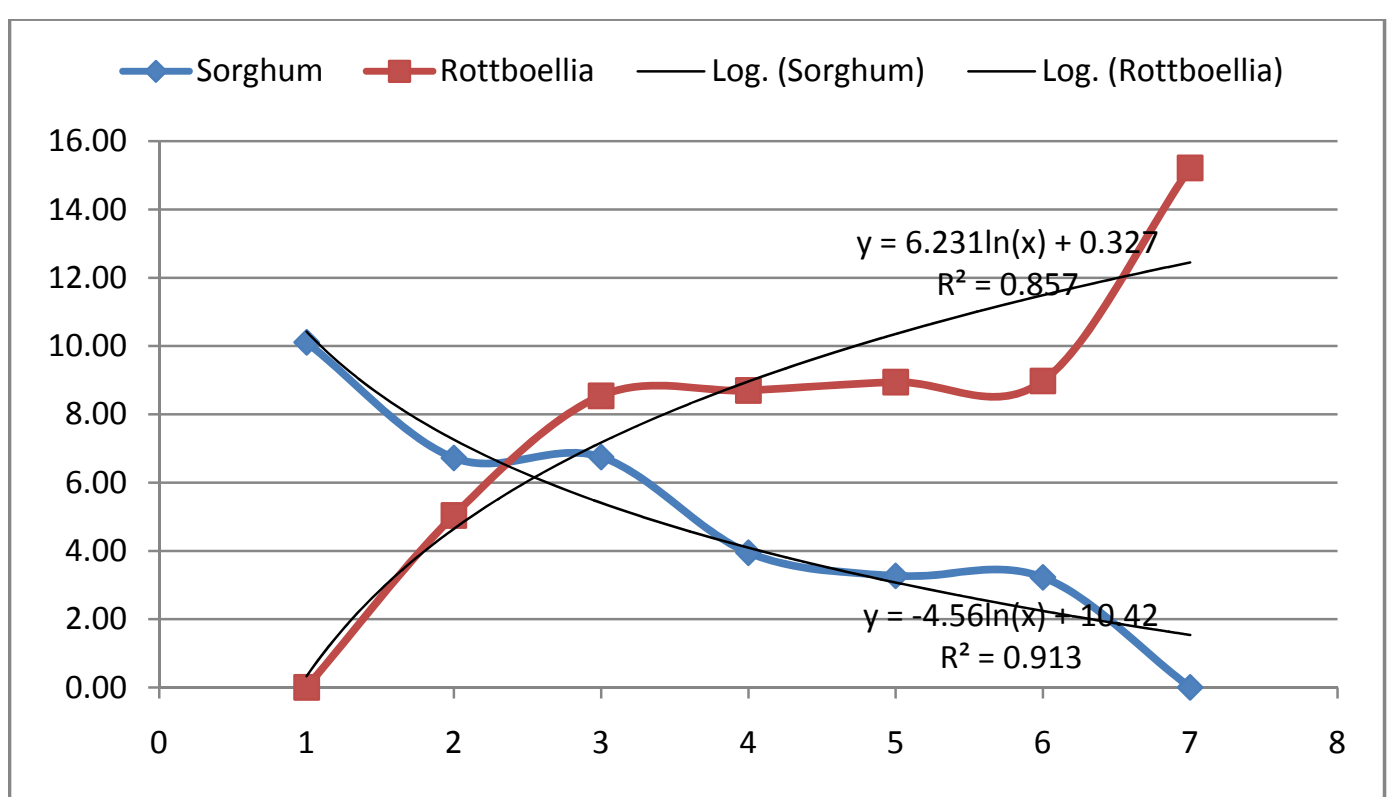

Gambar 3. Kurva Hubungan populasi dan biomassa pada tanaman sorghum dan gulma R.exaltata pada sistem polikultur $(1-7=$ berturut-turut sebagai kombinasi S36.R0, S30.R6, S24.R12, S18.R18, S12.R24, S6.R30 dan S0.R36)

Berdasarkan persamaan regresi pada gambar 2, maka kemampuan kompetisi untuk sorghum dan R.exaltata dapat ditentukan sebagai berikut :

$\beta=\frac{(1 / \Omega)}{\left(1 / \beta x^{1} / \Omega\right)}=0.076 / 0.054=1.407$

\section{Kemampuan kompetisi untuk sorghum}

$Y=a+b x$, yaitu $Y=0.076+0.054 x$

Kemampuan kompetisi untuk R.exaltata dimana $a=(1 / \Omega)=0,076$ $Y=a+b x$, yaitu $Y=0.06+0.14 x$

Dimana $a=(1 / \Omega)=0.06$

$$
\mathrm{b}=\left(1 / \beta x^{1 / \Omega}\right)=0.054
$$

$$
\begin{gathered}
\mathrm{b}=(1 / \beta \times 1 / \Omega)=0.14 \\
\beta=\frac{(1 / \Omega)}{\left(1 / \beta^{1 / \Omega}\right)}=0.06 / 0.14=0.428
\end{gathered}
$$


Pada R.exaltata kurva berat kering
juga semakin meningkat $\begin{array}{r}\text { dengan } \\ \text { bertambahnya }\end{array}$ populasi. kecenderungan yang terlihat dari kurva adalah bahwa apabila sorghum tidak terserang hama maka bobot kering sorghum akan lebih tinggi dibandingkan dengan R.exaltata. Fenomena ini menunjukkan bahwa sorgum memiliki daya kompetisi yang lebih tinggi. Hal ini juga terbukti dari nilai $\beta$ sorghum yang lebih tinggi.

\section{Kompetisi Interspesifik dan Koefisien Daya Desak}

Kompetisi interspesifik atau kompetisi antar jenis merupakan interaksi negatif yang terjadi pada tumbuh-tumbuhan yang berbeda jenis. Interaksi tersebut dapat dilihat dari penurunan berat kering yang terjadi pada tanaman yang berasosiasi. Gambar 3 menunjukkan bahwa dengan semakin bobot kering sorghum akan menurun dengan hadirnya R.exaltata.

Fenomena ini sangat berbeda pada kompetisi intra spesies pada jumlah populasi yang sama dimana daya kompetisi sorghum lebih tinggi dibandingkan R.exaltata. Hal ini diduga karena gulma memiliki daya desak yang lebih tinggi dari pada sorghum. Namun terjadi ketidak-konsistenan data sehingga sulit untuk mengambil kesimpulan yang

Tabel 5. Koefisien daya desak pada polikultur tanaman sorghum dan R.exaltata

\begin{tabular}{crr} 
Perlakuan & \multicolumn{2}{c}{ Koefisian Daya Desak (k) } \\
& Sorghum & R. exaltata \\
S30.R6 & 4.64 & 251.44 \\
S24.R12 & 11.23 & 115.25 \\
S18.R18 & 24.33 & 56.72 \\
S12.R24 & 44.96 & 27.93 \\
S6.R30 & 110.58 & 11.25
\end{tabular}

\section{KESIMPULAN}

Berdasarkan hasil percobaan, maka dapat diambil kesimpulan sebagai berikut:

1. Kemampuan kompetisi sorghum lebih tinggi dibandingkan R.exaltata pada penanaman monokultur
2. Terjadi ketidak-konsistenan data pada polikultur sehingga tidak dapat diperoleh daya desak yang benar.

\section{DAFTAR PUSTAKA}

Ampong-Nyarko, K. and De Datta, S.K. 1991. A Handbook dor Weed Control in Rice. IRRI, Philippines. 113 p.

Balai Informasi Pertanian provinsi Irian Jaya. 1990. Teknologi Budidaya Sorghum. Irian Jaya.

De Datta, S. K. 1981. Principles and Practicesof Rice Production. John Wiley and Sons. New York, Chichester, Tokyo, Toronto, Singapore.

Madkar, O.R., Tony K, dan Soepadyo M. 1986. Masalah Gulma dan Cara Pengendaliannya. Himpunan Ilmu Gulma Indonesia.

Moenandir, J., 2004. Prinsip-prinsip Utama Cara Menyukseskan Produksi Pertanian, Dasardasar Budidaya Pertanian. Fakultas Pertanian Universitas Brawijaya, Malang.

Moenandir, Jody. 1988. Persaingan

TAnaman Budidaya dengan Gulma (Ilmu Gulma-Buku III). Rajawali Pers, Jakarta.

Moody, K. 1991. Weed management in rice, p. 301-328. In : Pimentel D. (ed). Handbook of Pest Management in Agriculture. Boca Rato (Florida). CRC Press.

Sastroutomo, S. S. 1990. Ekologi Gulma. Gramedia Pustaka Utama. Jakarta.

SEAMEO-BIOTROP. 2010. Invasive Alien Species. www.biotrop.org

Sukman dan Yakup, 1991. Gulma dan Teknik pengendaliannya. Raja Grafindo. Jakarta.

Sutrisno., Purnomo Djoko., Turanto. 1980. Pengaruh Jawan (Echinochloa crussgalli L) Terhadap Pertumbuhan dan Produksi Sorgum IR 36. Prosiding Konperensi Ke-enam Himpunan Ilmu Gulma Indonesia. Medan 12-14 Februari 1981. 